\title{
"Valentes de batina": \\ a coragem e o uso da violência por clérigos em Goiás
}

\author{
"Brave men in cassocks": bravery and use of violence by clergymen in Goiás
}

\author{
Eliézer Cardoso de Oliveira * \\ Eduardo Gusmão de Quadros **
}

\begin{abstract}
Resumo
Este artigo analisa clérigos que se identificaram com a ética da valentia. A valentia é um campo valorativo baseado na demonstração pública de coragem e na perícia no manejo da violência. Nesse sentido, observou-se que, entre os clérigos católicos, um contingente minoritário, mas heuristicamente representativo, realizou ações típicas de pessoas valentes, como a coragem de matar outro ser humano ou de empregar a violência para resolver conflitos cotidianos. O texto está dividido em três partes: a primeira, denominada de "Igreja católica e violência", analisa, a partir da sociologia weberiana, as relações tensas entre religião e violência. Na segunda, "A valentia e os clérigos", procura-se conceituar valentia e demonstrar a sua aplicabilidade aos membros do clero a partir de exemplos históricos. Por fim, o tópico denominado "Padres valentes em Goiás" estuda os casos de padres, no contexto da história goiana, antes de 1930, que se aproximaram da ética da valentia, assumindo uma personalidade que destoa do comportamento socialmente esperado para essa categoria.
\end{abstract}

Palavras chaves: Ética da valentia; Catolicismo e violência; Clérigos; História de Goiás.

\begin{abstract}
This article analyzes clerics who identified with the ethics of bravery. Bravery is an evaluative field based on the public display of courage and skill in the management of violence. In this sense, it was observed that among the Catholic clergy, a minority contingent, but heuristically representative, held typical actions of brave people, like the courage to kill another human being, or to use violence to solve everyday conflicts. The text is divided into three parts: the first, called "Catholic Church and violence," says, from the Weberian sociology, the strained relations between religion and violence. In the second, "the courage and the clerics" looking conceptualize courage and demonstrate their applicability to members of the clergy from historical examples. Finally, the topic called "brave priests in Goiás" studies the cases of priests in the context of Goiás history, before 1930, which approached the bravery of ethics, taking on a personality that clashes with the socially expected behavior for this category.
\end{abstract}

Keywords: Ethics of valiance; Catholicism and violence; Clerics; History of Goiás.

\footnotetext{
Artigo recebido em 07 de maio de 2015 e aprovado em 22 de dezembro de 2015.

* Doutor em Sociologia, professor do curso de História e do Mestrado em Territórios e Expressões Culturais no Cerrado da Universidade Estadual de Goiás, cursando estágio pós-doutoral na PUC-GO. País de origem: Brasil. E mail: ezi@uol.com.br

** Doutor em História pela UnB, professor da PUC-GO e da Universidade Estadual de Goiás. País de origem: Brasil. E-mail: eduardo.hgs@hotmail.com
} 


\section{Introdução}

Conforme a descrição do capítulo 18 do evangelho de João, quando o destacamento de soldados enviado pelos sacerdotes judeus foi prender Jesus, Pedro reagiu à abordagem, ferindo com uma espada o servo do sumo sacerdote, decepando-lhe a orelha direita. Jesus condenou o ato de violência, ordenando que Pedro guardasse a espada e curou o ferimento do jovem Malco. A impetuosidade de Pedro foi perdoada e ele foi consagrado como chefe da Igreja. Esta manteve a ambiguidade do seu fundador, pregando uma ética pacifista e às vezes extravasando um comportamento violento. Uma parte dos membros do clero católico - minoritária, é verdade - destacava-se por uma identificação com uma ética da valentia, demonstrando coragem, maestria e familiaridade com a violência. Nesse sentido, este artigo tem como tema o estudo desses padres no contexto de Goiás, antes dos anos 1930.

A metodologia empregada na construção e fundamentação deste artigo poderia ser denominada de sociologia histórica ou história sociológica. Seguindo o caminho aberto por Max Weber, buscou, por meio da erudição histórica, fazer uma análise sociológica de um tema inusitado, mas pertinente para uma compreensão mais complexa do mundo da cultura. Foi construído um painel histórico, demonstrando os diversos níveis de aproximação dos clérigos com a ética da valentia ${ }^{1}$.

O texto está dividido em três partes básicas. A primeira, denominada de "Igreja católica e violência”, analisa, a partir da sociologia weberiana, as relações tensas entre religião e violência. A segunda, “a valentia e os clérigos”, procura

\footnotetext{
${ }^{1}$ Além de Max Weber, o uso de exemplos históricos numa temporalidade ampla para fundamentar uma análise histórico-sociológica foi utilizada por autores de diferentes matizes teóricas. Um desses autores foi Michel Foucault, acusado, a propósito de sua obra Vigiar e Punir, de ser um "cossaco da história, que gosta das grandes cavalgadas", percorrendo séculos de história à rédea solta. Foucault respondeu ao seu interlocutor - Jacques Leonard - que não objetivava estudar um período, mas analisar um problema (BOURDÉ; MARTIN, 1983, p.192). O argumento de Foucault pode ser utilizado para reforçar a metodologia empregada neste artigo. O passeio histórico realizado à rédea solta pela história do Cristianismo poderia até ser dispensável, mas é indubitável que ajuda a reforçar o estudo do problema em torno dos conflitos entre a ética da fraternidade e a tolerância e o uso da ética da valentia por parte da Igreja, ao longo dos séculos de sua existência.
} 
conceituar valentia e demonstrar a sua aplicabilidade aos membros do clero. Por fim, o tópico denominado "Padres valentes em Goiás" estuda os casos de padres, no contexto da história goiana, antes de 1930, que se aproximaram da valentia.

\section{Igreja católica e violência}

O que leva uma religião, como o catolicismo, derivada do pacifismo cristão, a legitimar a valentia? A resposta está no fato de que nenhuma religião ou sistema político é constituído apenas por um sistema ético puro, desvinculado dos interesses de ordem material. As religiões influenciam e também são influenciadas por forças sociais que estão a sua volta: elas precisam da legitimação do poder político constituído, do dinheiro dos homens ricos, do talento dos artistas para construção e embelezamento dos templos, da inteligência dos intelectuais para sistematização das ideias religiosas. Quando do início de sua fundação pelos líderes carismáticos ${ }^{2}$, as ideias religiosas conseguem manter certa autonomia em relação aos interesses mundanos. Contudo, quando ocorre o que Weber denomina de "rotinização do carisma", ou seja, uma institucionalização e hierarquização do corpo sacerdotal, gradativamente a ética religiosa passa a interagir com maior força com elementos externos a ela.

O elemento sociológico de maior interesse nesse processo de "rotinização do carisma" é o fato de as ideias originais do líder carismático adaptarem-se aos interesses de determinados grupos sociais. Esse ajustamento das ideias aos interesses é chamado por Weber de afinidade eletiva: cada grupo social seleciona as ideias afins aos seus interesses materiais e abandona as outras.

\footnotetext{
${ }^{2}$ Para Weber (1982, p. 284), o conceito de líder carismático abarca uma série de categorias, desde "médicos e profetas, tal como juízes e chefes, ou aos chefes de grandes expedições de caça". O decisivo é a capacidade de essas pessoas convencerem um grupo de adeptos de que possuem um dom (carisma) que lhes possibilita questionar o status quo vigente. No caso especificamente religioso, o líder carismático é denominado "profeta", que os adeptos acreditam ser portador de boas novas. Nesse sentido, os fundadores das grandes religiões - Jesus e Maomé, - ou os reformadores - Lutero, Calvino, Thomas Müntzer - são considerados como profetas. Já os sacerdotes são o antípoda do profeta, pois eles são responsáveis por sistematizar os ensinamentos do profeta em um conjunto de normas éticas, além de institucionalizar o culto por meio de normas. Enquanto, no caso do profeta o carisma está na pessoa, no caso do sacerdote, o carisma está no cargo.
} 
Desse modo, os camponeses, por exemplo, têm afinidade com uma religiosidade permeada de magia, bastante útil para quem é altamente dependente da aleatoriedade das forças da natureza (WEBER, 1994, p. 322). A pequena burguesia e os pequenos artesãos, pelo contrário, possuem afinidades com a "ética da retribuição”, ou seja, a garantia da salvação a partir de um comportamento ético exemplar (WEBER, 1994, p. 330). Já a aristocracia guerreira despreza valores como humildade e subserviência; ela busca na religião a oportunidade de exibição de sua força em rituais religiosos suntuosos ou na luta direta para converter ou exterminar os infiéis (WEBER, 1994, p. 323).

No caso do cristianismo, em períodos de maior influência social da aristocracia guerreira, houve uma aproximação mais destacada com a violência, seja a violência institucionalizada do Estado, seja a violência privada dos senhores de terras. Foi o caso do catolicismo durante a Idade Média europeia e também foi o caso do catolicismo em Goiás dos séculos XVIII, XIX e parte do XX. Nos dois contextos - o feudalismo e o coronelismo -, a força da aristocracia de homens valentes e rudes, com sua ética da valentia, influenciava fortemente o direcionamento do catolicismo, tornando-o mais coerente com o seu estilo de vida. A Igreja, talvez a contragosto, legitimava a violência dos senhores em troca de seu apoio político e dinheiro. Além do mais, grande parte dos sacerdotes eram filhos ou dependentes econômicos da classe dominante.

A legitimação do cristianismo à violência dos poderosos foi bem precoce. Ainda nos tempos de Constantino, Eusébio de Cesaréia (2000, p. 505) define como "vontade de Deus" a vitória do exército de Constantino sobre o de Licínio: "Como, em trevas espessas e noite muito escura, brilha subitamente um grande astro, Deus para salvação geral, levou pela mão a esta região seu servo Constantino”. A violência dos imperadores romanos, que tanta dor causou aos mártires cristãos no passado, agora era glorificada por um dos pais da igreja. A aceitação da guerra por parte dos cristãos foi sistematizada por Santo Agostinho. Ele, pessoalmente, era refratário à violência, a ponto de criticar a atitude de seu amigo Alípio que se 
deleitou com um espetáculo de violência e valentia dos gladiadores romanos: "deleitava-se no combate criminoso e inebriava-se no prazer sangrento" (SANTO AGOSTINHO, 200o, p. 157). Contudo, a sua crença na natureza pecaminosa humana, levou-o a defender que "Los cristianos no podían obviar que la paz era imposible en la tierra y, por tanto, no tenían otra opcíon que aceptar la existencia de la guerra y tomar parte en Ella para combatir el pecado, la maldade y la injusticia, al menos bajo ciertas condiciones" (FITZ, 2003, p. 124). Isso permitiu que, tempos depois, mais especificamente no natal de 800, o próprio papa Leão III colocasse a coroa em Carlos Magno, formalizando uma aliança entre religião e política que perduraria por séculos.

Apoiar a violência do Estado ou do segmento dominante era relativamente simples de ser justificado pela Igreja, como bem demonstrou Santo Agostinho. O mais complicado seria justificar a violência cometida por aqueles que deveriam pregar e ensinar a paz e o perdão. A oportunidade para a Igreja, oficialmente, sujar as mãos de sangue ocorreu com as cruzadas. Inicialmente, o papa urbano II, o pioneiro das cruzadas, conclamou, por volta de 1095, os cavaleiros a lutar contra os infiéis, sob o incentivo de que os mortos em combate garantiriam a salvação. Contudo, um cavaleiro franco, Hugo de Payns, condoído com a miserável situação dos cristãos na Terra Santa, maltratados por salteadores, juntamente com mais oito cavaleiros, fundaram, em 1118, a famosa ordem militar religiosa dos cavaleiros templários. Dez anos mais tarde, graças à intervenção de Bernardo de Claraval, a ordem recebeu a autorização e apoio do Papado.

Apesar disso, não foi simples a Igreja admitir o uso da força por parte de seus membros. É que

Se a ideia do guerreiro cristão lutando pela defesa circunstancial de sua religião não era de todo estranha ao medievo, a de um monge guerreiro em tempo integral o era. Causava estranheza tal mistura de missões. A imagem de um homem de oração empunhando uma espada, derramando sangue, cortando cabeças, ainda que de infiéis, levando uma existência aventureira, não era de modo algum facilmente assimilável. Repugnava a muitos. (SILVA, 2014, p. 70). 
Gradativamente, a repugnância cedeu diante da eficiência dos monges guerreiros. Acostumados à rígida disciplina dos monastérios, amplamente convictos da justiça de sua causa, os cavaleiros templários espalharam a fama de coragem, valentia e virilidade. Contudo, mesmo assim, a possibilidade de utilizar a violência não era irrestrita. O próprio Claraval, por exemplo, "condenava qualquer miliciano secular que matava ou morria inutilmente, sem servir a causa cristã". (SILVA, 2014, p. 87). A violência só seria admitida se expressasse a ira de Deus.

De qualquer forma, o surgimento dos templários e de outras ordens religiosas militares marcou um ponto de inflexão na história da Igreja. Pela primeira vez, ela admitiu cruzar a linha tênue que separava os membros do clérigo do manejo da violência. Alguns séculos depois, quando da época de heresias, como a dos cátaros ou albigenses, a violência excepcional das cruzadas transmutou-se na violência sistemática e burocrática dos tribunais inquisitoriais. Entre as duas violências sob a tutela eclesiástica, os tribunais conviveram numa duradoura simbiose com os instrumentos de coerção do nascente Estado moderno, enquanto as ordens militares católicas não resistiram ao processo de monopolização da violência legítima levado a cabo pelos monarcas absolutistas.

A fundação da Companhia de Jesus pelo ex-soldado Inácio de Loyola e sua legitimação pelo papa Paulo III em 1540 representa uma nova postura da Igreja, interessada em manter um exército de monges disciplinados e obedientes, mas que não estavam dispostos, eles mesmos, a praticar a violência. Era um novo tipo de coragem, baseada numa postura destemida diante de perigos, mas sem a utilização de qualquer tipo de armamento. Com isso, a Igreja retomava a postura de deixar a violência para os civis, muito embora legitimasse a violência praticada pelo Estado e, algumas vezes, por segmentos poderosos na sociedade. 


\section{A valentia e os clérigos}

Independente da posição da Igreja em tolerar ou não o uso direto da violência, alguns de seus membros se identificavam muito mais com uma postura viril do que com a humildade cristã. São pessoas que viveram uma relação tensa e conflituosa entre a fé religiosa e o gosto pela demonstração de coragem e honra.

Desse modo, muitos clérigos, em alguns momentos de suas vidas, foram seduzidos pela esfera da valentia, cujo principal valor é a coragem e a perícia em enfrentar desafios. Um desses padres, segundo as pesquisas do historiador Ronaldo Vainfas, foi o jesuíta paulista Manoel de Moraes, que, na primeira metade do século XVII, mobilizou os indígenas aldeados na luta contra os holandeses em Pernambuco, demonstrando um prazer pouco cristão pelas lides das batalhas. Manoel assustou os militares e até os oficiais da Companhia de Jesus:

Oficiais de Matias de Albuquerque viam com desconfiança, e alguma perplexidade, o papel cada vez mais importante que um simples padre passava a exercer na guerra, restrição compartilhada por diversos membros da Companhia, considerando o gosto que tinha Manoel pelo ofício militar. Manoel, na verdade, lutava e matava com garra, agindo como autêntico paulista nos matos, esquecidos dos mandamentos de Deus e de suas obrigações como sacerdote. (VAINFAS, 2008, p. 45).

Manoel era um padre valente. No entanto, apesar da clareza do adjetivo, a definição sociológica da valentia é uma tarefa um pouco complexa, uma vez que se trata de uma representação social variável historicamente. Embora possua elementos universais facilmente reconhecíveis, cada sociedade vai caracterizar e valorizar a valentia de modo diferenciado. Por exemplo, enquanto na sociedade do Antigo Regime, a valentia era amplamente reconhecida, nas sociedades burguesas houve uma maior restrição às demonstrações gratuitas de valentia.

Valentia está intrinsecamente ligada às categorias de honra, coragem e violência, mas não se confunde com nenhuma delas isoladamente. O conceito de 
honra possui significados diferenciados nas sociedades aristocráticas e nas sociedades burguesas: nas primeiras, honra era equiparado à coragem na utilização da violência; já nas segundas, honra equivaleria à honorabilidade, no sentido de moral e honesto (ELIAS, 1997, p. 96). A categoria “coragem” também admite uma disposição para praticar a violência (como a coragem do guerreiro) ou a disposição para fazer o que é certo moralmente (como a coragem do pacifista). Nesse sentido, a categoria "valentia", desconsiderando os seus usos metafóricos, emergiu em sociedades aristocráticas, onde era considerada como a síntese de honra, coragem e disposição e perícia para praticar ações violentas. Portanto, o valente é aquele que é encorajado a praticar a violência como uma forma de lhe garantir a honorabilidade entre o seu grupo social.

Desse modo, Weber, ao refletir sobre o conflito entre a ética do guerreiro e a ética da fraternidade de determinados sistemas religiosos, criou parâmetros para uma definição sociológica da valentia, inclusive, especificando os elementos que distinguem a conduta do guerreiro:

O modo de viver do guerreiro não tem afinidade nem com a ideia de uma providência bondosa nem com a de exigências éticas sistemáticas de um deus supramundano. Conceitos como "pecado", "redenção", "humildade" religiosa não apenas costumam estar muito distantes do sentimento de dignidade de todas as camadas politicamente dominantes, sobretudo da nobreza, como diretamente o ofendem. [...] Enfrentar a morte e as irracionalidades do destino humano com coragem é para o guerreiro uma coisa cotidiana, e os riscos e aventuras deste mundo ocupam tanto espaço em sua vida que não exige nem aceita de bom grado de qualquer religião outra coisa que não a proteção contra feitiçarias e ritos cerimoniais, adequados ao sentimento de dignidade estamental, que se tornam componentes da convenção estamental, e, quando muito, ainda preces sacerdotais pela vitória ou por uma morte feliz, que conduza ao céu dos heróis. (WEBER, 1994, p. 323).

Em termos da construção ideal weberiana, o valente é aquele que não recua diante do perigo da morte e que vive a vida como se ela fosse uma grande aventura. A princípio, o valente não deseja a morte, e os casos de missão suicidas de soldados se explicam mais pelo dever de honra do que pela busca individual da morte. $\mathrm{O}$ valente não quer morrer, mas o perigo da morte não é um freio para as suas ações. 
O reconhecimento social e existencial pela coragem demonstrada compensa o risco.

Um vigoroso exemplo desse destemor diante da morte foi a atitude do tenente-capelão Vicent Capodanno, do corpo de fuzileiros navais do exército norteamericano na Guerra do Vietnã. Ao ver uma companhia cercada pelo fogo inimigo, o capelão abandonou a sua segurança e correu em meio ao fogo cerrado para ajudar os seus companheiros. Indiferente aos disparos, ajudava os feridos e consolava os moribundos, até ser ferido nos braços e pernas por uma explosão de um morteiro que lhe arrancou parte de uma das mãos. Mesmo ferido, continuou com a sua missão, inclusive tentando salvar um paramédico que estava sob o fogo cerrado de uma metralhadora inimiga. Foi atingido pela metralhadora e morreu quase junto do paramédico que tentava ajudar. Por seu exemplo de bravura, foi condecorado com a Medal of honor, a mais alta do exército norte-americano. (CAPODANNO, V. R. Vietnam War).

Além da coragem de enfrentar a morte, a valentia tem outra faceta: a coragem de matar o semelhante. E isso é uma tarefa difícil, já que apenas uma proporção muito pequena dos seres humanos é capaz de executá-la. Segundo o estudo do tenente coronel norte-americano David Grossman, autor do livro On Killiing: the Psychological Cost of Learning to Kill in War and Society, outras espécies animais também evitam matar entre si, como é o caso das cobras que lutam com o corpo, evitando expelir o mortal veneno. Mesmos os soldados, teoricamente preparados para matar, evitavam propositadamente acertar o inimigo com os seus tiros (GROSSMAN, 1996. p. 22). Durante a Guerra Civil norte-americana, o autor estima que menos da metade atirou em seus inimigos e, dos que atiraram, uma ínfima parte tentou realmente matar os seus inimigos. Durante a I Guerra Mundial, menos de 20\% dos soldados americanos tentaram realmente matar o seu inimigo. 
Não se sabe ao certo, o que provoca essa aversão ao ato de matar. Grossman postula a hipótese da existência de uma espécie de trava inibidora, de natureza inconsciente, com a função de impedir que os humanos exterminem uns aos outros (GROSSMAN, 1996, p. 38). Contudo, nem todos parecem ter essa repugnância, como é o caso dos sociopatas; além disso, existem mecanismos psicológicos que podem inibi-la. São técnicas de desumanização e brutalização, utilizadas nos treinamentos militares modernos, que, satisfatoriamente, atingiram o seu objetivo. Na Guerra do Vietnã, o índice de soldados dispostos a atirar para matar em seus inimigos foi superior a 90\%. Entre os civis, aqueles criados em um ambiente que estimula a brutalização também possuem maior aptidão para matar o outro do que as pessoas que vivem em um ambiente mais cordato.

Portanto, soldados, criminosos, sociopatas, são um seleto grupo dos seres humanos dispostos a matar. Já a situação dos padres que cometeram algum tipo de assassinato é mais difícil de ser explicada, uma vez que eles tiveram uma formação religiosa voltada justamente para amar o próximo. Em muitas situações, como foi o caso dos templários, foi preciso criar uma ideologia que desumanizasse o infiel, para justificar a sua morte. Os monges acreditavam que eram apenas instrumentos da ira de Deus e não meros assassinos. Parece ser o caso também do que é, provavelmente, o mais famoso padre assassino da história, o dominicano Jacques Clément, que, em 1589, assassinou a facadas o rei francês Henrique III, no contexto das guerras religiosas entre católicos e protestantes. O padre, como era de praxe entre os regicidas, foi morto de modo atroz pela guarda real. Um indício bem convincente do duro espírito da época - o papa Sixto V considerou o padre um mártir e chegou a cogitar a sua canonização (CASTILHO, 1906, p. 331). Em tempos mais recentes, muitos clérigos se integraram a movimentos guerrilheiros na luta contra as ditaduras latino-americanas, imbuídos da crença, como foi o caso do padre colombiano Camilo Torres, de que "El ultimo recurso que nos queda es la violência revolucionaria" (BROODERICK, 1996). 
No Brasil, um caso de ampla repercussão foi o assassinato, em 1957, do bispo de Garanhuns, Dom Expedito Lopes, pelo padre Hosana de Siqueira e Silva, simplesmente porque o bispo exigiu que o padre cumprisse adequadamente o celibato e tivesse uma conduta religiosa exemplar, sob pena de suspensão. De acordo com a revista $O$ Cruzeiro

E no dia em que seria publicado o ato episcopal suspendendo as ordens sacerdotais de Hosana, que fêz o padre-assassino? Dirigiu-se ao Palácio Episcopal de Garanhuns e apertou a campainha da porta. O próprio bispo atendeu, e quando dizia "faça o favor de entrar", Hosana fulminou-o com 3 tiros de um "Taurus" 32, que tomara emprestado a um conhecido na véspera. (SILVA, 1960).

O padre Hosana, depois de três julgamentos, foi condenado e depois libertado por bom comportamento em 1967. Em 1997, foi encontrado morto com suspeita de ter sido assassinato. Dom Expedito se tornou objeto de inúmeras homenagens e foi aberto, inclusive, um processo visando a sua possível canonização (MOREIRA, 2008, p. 64).

O caso do padre Hosana é raro, pois ele não apenas desobedeceu ao $5^{\mathbf{0}}$ mandamento como também à regra de obediência a seus superiores. Raro também foi o caso do padre ruandês Athanase Seromba, que foi o primeiro sacerdote católico condenado pelo tribunal internacional por genocídio. Segundo um site de notícias do Vaticano:

Em 1994, Pe. Athanase Seromba tinha a seu cargo a paróquia de Nyange, na localidade de Kivumu, província ocidental de Kibuye. Fugindo dos massacres, mais de duas mil pessoas, a maioria da comunidade tutsi, encheram a igreja de Nyange que, a partir de 15 de abril de 1994, foi alvo de ataques regulares, por parte de militares e milícias. Segundo a acusação, o sacerdote ordenou a destruição da igreja, com máquinas escavadoras, que mataram os poucos sobreviventes aos ataques dos militares e das milícias. (VATICANO, 2006).

Contudo, a valentia não se restringe aos polos: coragem de arriscar a própria vida e coragem de tirar a vida alheia. Há versões mais moderadas, nas quais as pessoas fazem uso da agressão física, mas não chegam ao extremo de 
matar e de morrer. Nesse caso específico, trata-se da luta e da briga. A luta é exercida por atletas que preparam o seu corpo e sua mente para um combate, dentro das normas estabelecidas pela modalidade, como é o caso dos boxeadores ou dos lutadores de vale-tudo. A briga é exercida por amadores em situações cotidianas de conflito, embora alguns possam ser tão eficientes no manejo de técnicas de violência que fariam inveja aos lutadores profissionais.

Há uma incompatibilidade entre a função eclesiástica e a de lutadores profissionais, embora alguns sacerdotes sejam praticantes de artes marciais, como o controverso ex-vigário da cidade de Pirenópolis, Joel Alves de Oliveira, praticante do caratê (Paiva, 2007). Num passado remoto, a conciliação entre a função sacerdotal e o prazer pelos jogos marciais era bem menos complicada. $\mathrm{O}$ papa renascentista Júlio II, o "papa guerreiro", contrariando as normas da Igreja, comandava pessoalmente as suas próprias forças de combate (BURKHARDT, 1991, p. 75).

O certo é que a formação religiosa nem sempre é suficiente para evitar que alguns sacerdotes deem vazão a sua ira em forma de agressão física. Foi o que aconteceu, em Ituiutaba (MG), 1997, com o padre Francisco de Assis, que, numa atitude oposta ao santo homônimo, ficou irritado com uma fiel que

estava presente sem ter sido convidada para o batizado e expulsou-a da catedral enquanto celebrava a cerimônia. Como Silvéria resistiu, o padre jogou a água da pia batismal em cima dela. Em seguida, fora de controle, ele atacou a mulher a socos e pontapés e foi contido pelas pessoas que assistiam à cerimônia. (SGARIONI, 1997).

Padre Francisco não é nenhum Frei Tuck e a sua agressão a uma senhora não é apropriadamente um ato de valentia. No entanto, a sua atitude, como a de outros colegas citados anteriormente, expressa certa virilidade que destoa da representação social construída sobre os clérigos. De acordo com o Jean-Marie Le Gall, 
Proibido de caçar, de dançar, de duelar, de interessar-se pelas moças, de fartar-se na taverna, de frequentar feiras e mercados, o clérigo foge às práticas que geralmente constroem coletivamente a virilidade. (LE GALL, 1013, p. 255).

O clérigo não anda armado, não usa barbas, usa uma vestimenta - a batina mais próxima a uma indumentária feminina, possui uma voz mansa e reconfortante. Por isso, quando se percebem atitudes que se aproximam de uma ética da valentia, há um assombro social. Ordinariamente, se esquece de que os sacerdotes não estão situados numa bolha sociológica que os torna imunes às influências sociais. Eles são sujeitos sociais e, como tais, vivem as contradições e dificuldades de manter a coerência de suas convicções.

\section{Padres valentes em Goiás}

Goiás, desde o início da colonização portuguesa, no século XVIII, foi um lugar marcado pela violência e, consequentemente, pela valorização da ética da valentia. Região afastada do litoral, constituía-se num dos lugares mais isolados da colônia portuguesa. Era mais fácil chegar nos longínquos rincões do Mato Grosso ou do Pará, por meio da navegação de rios, do que chegar a Goiás, por meio de tropas de montarias.

Mesmo assim, o fascínio do ouro atraiu intrépidos aventureiros que enfrentaram uma natureza inóspita, guerrearam com os bravios indígenas nativos e trouxeram subjugado o negro africano. Esse ambiente, marcado por um Estado fraco incapaz de minimizar a violência, pela guerra constante, pela escravidão e pela ruralização intensa, suscitava e estimulava a violência e a brutalização.

Até a religiosidade católica foi afetada pela intensa violência na vida cotidiana. Num lugar chamado Desemboque, os fiéis só assistiam à missa armados de pistola e facas (SILVA E SOUZA, 1998, p. 80, nota 6). As marcas de uma ética 
da valentia são visíveis em muitos rituais religiosos existentes em Goiás, que apresentam, invariavelmente, um caráter marcial, exibindo uma indumentária e uma performance de guerreiros. As Cavalhadas, por exemplo, simulavam um combate de cavaleiros fortemente armados entre mouros e cristãos e eram uma festividade típica de muitas localidades goianas do século XIX (Goiás, Meia Ponte, Corumbá e Santa Luzia). Os principais componentes da Procissão do Fogaréu são os Farricocos, mascarados com archotes representando os soldados romanos, que, na Sexta Feira Santa, simulam a prisão de Jesus Cristo. Na Festa do Encamisado, também cavaleiros vestidos de branco e com archotes nas mãos, faziam manobras marciais na praça principal da, então, Vila Boa de Goiás. Na dança do Congo, os negros simulam um "combate entre guerreiros armados de espadas ou tocadores de marinha” (BRANDÃO, 2004, p. 150). Esses rituais expressam o caráter aristocrático da ética religiosa da nobreza guerreira europeia e africana. Não foram originários de Goiás, mas o que é digno de nota é que aqui eles caíram no gosto popular, o que explica o fato de as Cavalhadas e a Procissão do Fogaréu serem, atualmente, duas das mais importantes manifestações culturais goianas. O gosto por rituais desse tipo é típico de povos que, conforme Max Weber, adaptaram sua crença no cristianismo ao seu gosto pela valentia e pela demonstração de força, perícia no manejo de armas e cavalos, disciplina militar e de prestígio estamental.

Isso demonstra que, de modo parecido com o que aconteceu na Idade Média europeia, a Igreja em Goiás dos séculos XVIII, XIX e parte do XX, adaptava-se a um contexto dominado por uma aristocracia rude, violenta, corajosa, mas fervorosamente religiosa. A sua atuação era marcada por uma ambiguidade de, ao mesmo tempo, amenizar a violência daqueles tempos e também legitimar (e até mesmo participar) os atos violentos praticados na época. A Igreja estimulava a paz, mas era afetada pelo respingo da guerra.

O papel contemporizador dos clérigos ficou evidenciado ainda na célebre bandeira de 1722, considerada o marco inicial da colonização portuguesa de Goiás. O capitão Bartolomeu Bueno da Silva, o Anhanguera, desentendeu-se com o seu 
genro, João Leite da Silva Ortiz, a pretexto de acampar para recompor as forças ou prosseguir na jornada. De acordo com o cronista Silva e Souza (1998, p. 76), "chegaram a tomar as armas um contra o outro, sendo necessária toda a prudência dos religiosos e das pessoas sensatas para conter e pacificar uns homens de quem a desesperação chegava ao furor desatinado”. Os religiosos em questão eram o frade beneditino George e o frade franciscano Cosme, que justificaram, nesse incidente, o porquê de os bandeirantes não adentrarem o sertão sem a presença de ao menos um clérigo.

De igual modo, a religião contribuiu para apaziguar os ânimos, em 1760, no Arraial de Santa Luzia (atual Luziânia), quando o sertanista “pacificador" de indígenas, João de Godoy Pinto da Silveira, refugiou-se na capela de Santa Luzia por conta de uma briga com o juiz José Pereira Lisboa e outros graúdos de Santa Luzia. O motivo da briga teria sido uma disputa por posições na procissão da Semana Santa de 1760. Depois de ser chamado de "capitão dos caboclos”, Godoy teria arrancado a peruca de Lisboa e batido com ela no seu rosto. Em represália, o juiz mandou, conforme carta de Godoy,

repetidas vezes a seus escravos, e ditos capitães do mato [que] me atirassem à espingarda a fim de me matarem: assim o executarão os mesmos descarregando-me vários tiros; dos quais um só disparou, ferindo-me o braço direito; e com as mais penetrantes feridas que me fizeram na cabeça, deixaram-me com evidente risco de vida. Assim maltratado, recolhi-me a Igreja Matriz para obviar o furor daqueles régulos: na qual estive alguns dias, até que pela misericórdia de Deus, recobrei forças para com novos alentos servir a Vossa Majestade [...]. (Carta do Capitão Mor da Conquista do Gentio na Capitania de Guayaz, João de Godoy Pinto da Silveira, ao Rei de Portugal. Arraial da Anta, 28 de maio de 1760. In. BERTRAN, 2000, p. 116, nota 21).

Se não fosse o respeito de seus perseguidores pelo local sagrado, Godoy teria abruptamente encerrado sua carreira de matador de indígenas. A autoridade moral da Igreja serviu de freio aos ímpetos dos valentões.

Em outros momentos, os próprios sacerdotes tomaram a iniciativa de, pessoalmente, debelar algum conflito. Foi o que aconteceu com o padre Luiz 
Gonzaga de Camargo Fleury que, em 1823, durante os distúrbios ocorridos no contexto da Proclamação da Independência do Brasil, foi ao Norte da província de Goiás dissuadir um violento movimento separatista e antilusitano. Ele se ofereceu como um contraponto pacífico à alternativa aventada pelo Imperador de enviar tropas para esmagar dissidentes. Pela sua atitude conciliatória, feita sem derramamento de sangue, o padre Fleury foi cognominado de o "Pacificador do Norte" (COSTA, 2013, p. 26).

Muitas vezes, os padres foram vítimas desse ambiente violento. Ainda no século XVIII, os habitantes do arraial de Santa Cruz não aceitaram a substituição do vigário e expulsaram o recém-nomeado Diogo Barbosa Rebello, não se importando nem um pouco com a convalescença do padre (SILVA E SOUZA, 1998, p. 80, nota 6). Contudo, em muitas ocasiões, os padres goianos envolveram-se diretamente em ações de violência. Numa carta à Rainha de Portugal, datada do ano de 1782, o vigário de Vila Boa de Goiás, denunciou que o padre José Simões de Motta Medeiros, apesar de condenado à prisão pelo Visitador Geral, conseguiu, graças à proteção do Governador Luís da Cunha Menezes, um salvo conduto para residir impunimente no Arraial de Traíras, onde mandou dar um tiro no padre Francisco Xavier das Chagas Vidal (NORONHA, 29 jun. 1782). Essa atitude nem um pouco fraternal entre os usuários da estola reforçou a má fama do clero goiano, a ponto de o historiador José Pereira de Alencastre (1979, p. 88) afirmar, com certo exagero3, que se tratava do "clero mais depravado, licencioso e devasso que se tem visto".

O próprio Alencastre cita outros exemplos de padres valentões em Goiás do século XVIII:

\footnotetext{
${ }^{3}$ Sobre o exagero crítico de Alencastre e de outros cronistas ao clero, são pertinentes as palavras abalizadas de José Luiz de Castro (2006, p. 92): "Devemos evitar os exageros interessados dos contemporâneos coloniais e de certa tradição liberal representada por autoridades, historiadores, cronistas e viajantes que encontraram argumentos para o seu anticlericalismo. [...] É possível perceber que o clima de violência existente nas primeiras décadas de mineração tenha influenciado o comportamento desses homens que viviam distante de seus superiores. Ser padre no Rio de Janeiro era diferente do pastoreio nos sertões de Goiás".
} 
Citam-se com horror as proezas que em Meia Ponte praticara o padre José Caetano Lopes Pereira, os assassinatos que mandara perpetrar, e suas lutas frequentes com as autoridades, das quais menoscabava confiado nas imunidades clericais. O padre Antônio de Oliveira Gago, que acompanhou Bueno na sua segunda entrada, alcançou também celebrizar-se por seus crimes, assim como muitos outros. (ALENCASTRE, 1979, p. 112).

Dentre os crimes cometidos pelo padre Gago, imputa-lhe mortes, açoites e muito outros excessos. Já o padre José Caetano Lobo Pereira, de Meia Ponte, acompanhado de mais 80 escravos armados, enfrentava juízes e expulsava e apropriava dos bens de sua vizinhança. O padre Passos de Pilar desdenhava do corregedor, passeando na sua frente "a cavalo com pajens armados de bacamartes." (SILVA E SOUZA, 1998, p. 80, nota 6). Contudo, o cronista Alencastre, diferente do seu colega Silva e Souza, teve uma apreciação bem mais positiva do padre Passos, admirando a sua coragem ao encabeçar, a pedido do Governador João Manoel de Menezes, uma bandeira na região do Araguaia, para procurar as míticas jazidas de ouro dos Martírios e dos Araés. A referida bandeira teve um fim trágico: os indígenas que habitavam as margens do Araguaia puseram fim à vida intrépida do padre bandeirante (ALENCASTRE, 1979, p. 144).

Outro religioso, do período colonial, familiarizado com as armas foi o missionário Manoel de Santana Alves que, em 1802, chegou ao Arraial de Natividade, trazendo um "numeroso séquito de criados e escravos, conduzia também consigo relíquias de santos e um grande arsenal de objetos religiosos" (ALENCASTRE, 1979, p. 279). Logo, suas atitudes meio messiânicas conflitaramse com o padre do arraial, o vigário Luiz José Custódio. Sem apoio da população local, o padre Custódio recorreu ao ouvidor, que enviou uma tropa para debelar o grupo de Santana Alves, que liderou a resistência, chegando a atirar com uma pistola contra a tropa do ouvidor. No entanto, a valentia do padre Alves era de araque: "no outro dia escreveu ao ouvidor com muita humildade, pedindo perdão dos crimes que havia cometido" (ALENCASTRE, 1979, p. 280). Ficou um tempo preso e depois desapareceu da região. 
Já no tempo do Império, em 1862, houve em Rio Verde, termo de Catalão, um sacerdote que usou da violência para defender os seus interesses libidinosos:

o padre Manoel Luiz Mendes mandou espancar a um indivíduo de nome José Rufino por suspeitar de relações entre ele e a sua amásia; esta em vindita procurou capangas, entre os quais José Rodrigues Tolheiro para assassinarem os espancadores de José Rufino. Prevenido o Padre esperou em casa: houve tiros e um ferimento. (ALENCASTRE, 1 jun. 1862, p. 6).

O sangue frio e a familiaridade com as armas do padre Rufino se apequenam diante dos feitos atribuídos a um missionário capuchinho, numa aldeia dos indígenas Xambioá, às margens do Araguaia. De acordo com o relato do religioso francês frei Michel Berthet, que viajou pelo norte da província de Goiás entre os dias 16 de maio e 21 de novembro de 1883, um missionário capuchinho, responsável por um projeto de catequese indígena, envolveu-se em um conflito com os indígenas por causa do furto de uma carga de sal. Ao descobrir que os indígenas eram responsáveis pelo furto, o missionário

os intima a restituírem o que tinham tão vergonhosamente roubado à sua vista, mas eles se recusam e se põem na defensiva. Logo se trava a luta entre os índios e a caravana do padre. Enquanto que, com água até os joelhos, ele segura duas barcas, trinta índios são mortos; uns dizem cinquenta, outros, oitenta. Finalmente, afirma-se que o padre sozinho matou trinta. (BERTHET, 1982, p. 142).

Frei Michel Berthet não cita o nome do Capuchinho envolvido no conflito com os indígenas. No entanto, o historiador Cônego Trindade, em seu livro Lugares e pessoas, analisando o trabalho dos missionários capuchinhos em Goiás, registra um conflito que envolveu o frade Sabino (sic) de Rimini, de "temperamento arrebatado", a ponto de "ser co-responsável indireto na morte do cacique dos Chambiaós, cujo o assassino fora um seu empregado" (Silva, 2006, p. 417-8). Esclarecido o autor, resta elucidar melhor o fato e, com isso, vem a dúvida: qual relato é o mais crível, o de Berthet ou o de Trindade? 
O artigo do pesquisador Odair Giraldin acrescenta importantes elementos na análise desse macabro acontecimento. Ele enumera três versões sobre o massacre na aldeia Xambioá. A primeira é do próprio Savino Rimini que, numa carta enviada aos seus superiores, de agosto de 1873, confirma que houve um conflito entre a sua comitiva e os indígenas por causa do roubo do sal, afirmando que "graças a Divina Providência não tive de lastimar entre minha pera gente, nem um so ferido, e dos Indios regulo uns 30 mortos, e outros tantos feridos" (RIMINI apud GIRALDIN, 2002, p. 11). A segunda versão é também do próprio Rimini, mas escrita bem depois, no seu livro de memórias, Tra i Salvaggi dell'Araguaya, publicado em 1925. Nele, ele relata que, ao tomar satisfação com os indígenas, foi atacado primeiramente pelo Cacique Deriodó e, na luta que se seguiu, o indígena foi morto por um dos homens da comitiva. Para se proteger dos indígenas enfurecidos, Rimini ordenou, então, que seus homens abrissem fogo, o que culminou em dez indígenas fulminados (GIRALDIN, 2002, p. 12). A outra versão foi a do julgamento realizado na Cidade de Goiás, que teve como réu o Frei, os soldados e os civis que participaram do massacre. Nesse julgamento, das cinco testemunhas apresentadas - nenhuma era indígena -, apenas uma relatou o número de três indígenas mortos, enquanto as demais relataram que apenas o cacique Deriodó foi morto. Ao ser questionado pelas suas versões anteriores, Frei Savino respondeu "que este número, de 30 mortos, fora dado por seus soldados e que ele não vira exatamente o que aconteceu no episódio, pois havia ficado longe dos acontecimentos." (GIRALDIN, 2002, p. 13).

Numa aritmética em que qualquer número acima de zero é muito, o relato de que um missionário foi responsável pela morte de 30 indígenas em um combate parece sair das páginas dum folhetim do Western americano. A se valer do princípio da Navalha de Occam, que postula que, geralmente, os relatos mais simples têm maior probabilidade de serem verdadeiros, o acontecimento fica pouco crível. Por outro lado, fica difícil compreender as divergências nos relatos de Frei Savino: por que ele inflaciona os números de mortos? Será que queria 
construir sobre si uma áurea de valentia? Conhecendo a estratégia dos governantes da época, em camuflar os acontecimentos, não é nada impossível que tenha havido mesmo uma grande carnificina entre os Xambioás4. De qualquer forma, o capuchinho capitalizou o acontecimento para criar uma identidade associada à valentia: andava sempre armado de revólver e era conhecido como o "terror dos índios".

Entre todos os eclesiásticos analisados nestas páginas, nenhum deles aproximou-se mais sistematicamente de valores ligados à valentia e ao poder político do que o Padre João Lima, na cidade de Boa Vista (atualmente, Tocantinópolis - TO), já na época dos coronéis da República Velha. Adaptando-se bem a um lugar marcado por disputas políticas sangrentas entre os caudilhos locais, Padre João, aproveitando-se da respeitabilidade eclesiástica, derrotou adversários poderosos, tornando-se o principal líder político da cidade, a terceira maior de Goiás na época. Configurou-se um caso sociológico raro - o mais famoso expoente em nível nacional é o padre Cícero - de coronel e padre em uma só pessoa. Para o historiador Luís Palacin, essa situação acarretava um conflito entre a ética da fraternidade cristã e o maquiavelismo político, que o padre autojustificou ao seu modo:

A subida do padre João ficava, certamente, balizada de sangue. Certa ocasião, D. Alano, então bispo de Porto Nacional, a quem sempre intrigou e preocupou a situação do padre João a cavalo entre a religião e a política, atreveu-se a perguntar-lhe diretamente: "Padre João, o Sr. já matou muitos homens, como dizem?" "Não Sr. Bispo, eu não matei ninguém, só matei cobras. Que se faz com uma cobra venenosa? Esmagamos sua cabeça". (PALACIN, 1990, p. 170).

A atuação política do padre acarretou uma fama, difundida por seus adversários, "de homem destemido, que tem sua cabroeira pelo sertão, de armas sempre pronta para guerrilhas" (CORREIA, 1977, p. 49). O fato é que o seu estilo

\footnotetext{
${ }^{4} \mathrm{O}$ texto evasivo e lacônico do relatório do presidente da província, referente ao ano de 1874 , dá margens à teoria de que as autoridades tentaram abafar o massacre: "Chegando ao conhecimento d'esta presidência o desagradável sucesso que se deo entre o diretor d'este aldeamento e os índios do mesmo nome [...], tratou ella logo de proceder às necessárias indagações para o conhecimento da verdade, que foi confirmada com a própria comunicação do referido missionário." (ASSIS, 10 jun. 1874, p. 38).
} 
de vida era típico de um guerreiro, sempre pronto para uma batalha. Evitava sentar de costas para portas e janelas e nunca usava os caminhos comuns em suas jornadas e nem revelava os detalhes de seu itinerário, para evitar possíveis tocaias (PALACIN, 1990, p. 171). Inclusive, sofreu algumas, sendo atingindo por um tiro no ombro enquanto se banhava em um ribeirão (CORREIA, 1977, p. 47). Padre João conciliou, para si mesmo e para o povo, as funções de padre e coronel até o fim. Diferentemente, outro sacerdote picado pela mosca da valentia, o padre Manoel de Macedo Carvalho Júnior, que abandonou os seus afazeres na cidade do Rio Bonito (atual Caiapônia) para se alistar na Coluna Prestes, justamente para combater o coronelismo do interior do Brasil.

Em Goiás, até o bispo era valente. Trata-se de Dom Eduardo Silva, que no período do seu bispado (1890-1907) procurou aplicar os princípios do Ultramontanismo5 a fim de moralizar os costumes do clero e do povo goiano. Uma das medidas de maior impacto, nesse sentido, foi convocar ordens religiosas estrangeiras para assumir as funções lúdico-religiosas antes exercidas por leigos. Nesse sentido, com ajuda da ordem dos padres redentoristas alemães, procurou colocar sob o controle direto da Igreja a famosa e lucrativa romaria de Barro Preto. A fim de retirar o controle das rendas da romaria das mãos dos coronéis Anacleto e Gonçalves, D. Eduardo foi interpelado: “se dessem mais um passo à frente, disparamos as garruchas, que apontavam para nós estando eles com os dedos no gatilho" (SILVA, 2007, p. 162). No entanto, os integrantes da comitiva que acompanhava o bispo retrucaram: "E nós disparamos também as nossas". Foi um momento de tensão em que dezenas de homens armados se encaravam frente a frente, dentro de uma igreja, prontos para desencadear uma grave carnificina. Felizmente, D. Eduardo cedeu e retirou-se do lugar sem que houvesse derramamento de sangue. O bispo negou que soubesse que seus acompanhantes estavam armados, mas ele foi denunciado à Nunciatura Apostólica, por um clérigo que o acompanhava, por valer-se de jagunços para controlar a romaria. 
Enfim, Goiás era um lugar de, nas palavras do escritor Hugo de Carvalho Ramos, "Terras bárbaras, gente forte" (RAMOS, 1984, p. 51). Muitos clérigos, como homens de seu tempo, foram marcados pela dureza e brutalidade do sertão. E na sua função religiosa, nem sempre se valeram somente de armas espirituais.

\section{Conclusão}

Os casos dos clérigos apresentados neste artigo devem ser mensurados em termos de tipos ideais de religiosos que, em maior e menor grau, tiveram afinidades com a ética da valentia. Esses homens agiram de modo diferente do que, tradicionalmente, espera-se de um sacerdote católico, demonstrando um destemor diante da morte e da capacidade de matar e uma disposição em valer da violência para resolver conflitos.

A própria Igreja, por séculos, ficou indecisa entre a ética da fraternidade e a ética da valentia. Às vezes, tolerou e estimulou a violência cometida pelos leigos; noutras vezes, permitiu que seus próprios membros se valessem da força em nome de preceitos cristãos. Apenas recentemente, após o Concílio do Vaticano II, a Igreja foi mais incisiva em condenar a violência, inclusive repudiando a violência do Estado na violação dos direitos humanos.

Se a Igreja demorou tanto para resolver, em termos doutrinários, a questão da violência, seus sacerdotes não estão completamente imunes ao fascínio da valentia, como deixam bem claro os casos citados neste texto. É claro que, atualmente, o contexto é bem diferente de Goiás do final do século XIX, quando um missionário acusado de matar indígenas foi absolvido num julgamento, no mínimo, irresponsável. A restrição do Estado e da própria Igreja às ousadias dos

\footnotetext{
${ }^{5}$ Segundo Mota e Quadros (2011, p. 40), a orientação do catolicismo em Goiás, após a segunda metade do século XIX, foi a do Movimento Ultramontano, que enfatizava que a Igreja era uma "organização religiosa constituída à moda militar, destinada a combater o poder diabólico". Essa orientação militar estimulava uma aproximação com a ética da valentia.
} 
valentões é muito maior do que foi no passado.

De qualquer modo o texto serve como um alerta para a força dos fatores culturais da violência. Ele demonstra o quanto a ética da valentia é sedutora, pois se até os padres, treinados para resistir ao Mal, muitas vezes sucumbiam a ela, o que dizer dos simples mortais?

É claro que, evidentemente, os casos citados aqui são uma ínfima minoria do clero católico. A maior parte dele, numa proporção bem maior do que entre os leigos, é de homens cordatos e devotos da humildade. Dos 12 discípulos de Cristo, apenas Pedro carregava consigo uma espada, disposto a usá-la se fosse preciso. Compreender e não julgar esses homens foi a proposta deste artigo.

\section{REFERÊNCIAS}

ALENCASTRE, José Martins Pereira de. Anais da Província de Goiás (1863). Goiânia: Gráfica do Cerne, 1979.

ALENCASTRE, José Martins Pereira. Relatório lido na abertura da Assembleia Legislativa de Goyaz pelo Presidente da Província. 10 jun 1862. Disponíveis em: <http://brazil.crl.edu/bsd/bsd/u186/o00007.html> e <http://www.crl.edu/content/brazil/goi.html>. Acesso em: 22 out 2015.

ASSIS, Dr. Antero Cícero de. Relatório apresentado à Assembleia Legislativa Provincial de Goyaz. 1 de jun 1874. p. 38. Disponível em:

<http://brazil.crl.edu/bsd/bsd/324/ooo038.html>. Acesso em: 22 out 2014.

BERTHET, Michel L. Uma viagem de missão pelo interior do Brasil. Memórias

Goianas. Goiânia: UCG, 1982. p. 109-170.

BERTRAN, Paulo. História da terra e do homem no Planalto Central. Brasília: Verano, 2000.

BOURDÉ, Guy; MARTIN, Hervé. As escolas históricas. Lisboa: Publicações EuropaAmérica, 1983.

BRANDÃO, Carlos Rodrigues. De tão longe eu venho vindo: símbolos, gestos e rituais do catolicismo popular em Goiás. Goiânia: UFG, 2004.

BROODERICK, W. Camilo Torres Restrepo. In. Archivo Chile. Disponível em: <http://www.archivochile.com/Homenajes/camilo/s/H_doc_sobre_CToo37.pdf>. Acessado em: 21 dez. 2015. 
BURKHARDT, Jacob. A cultura do Renascimento na Itália: um ensaio. Tradução de Vera Lúcia de Oliveira Sarmento e Fernando de Azevedo Corrêa. Brasília: Editora da UnB, 1991.

CAPODANNO, Vicent R. Vietnam War: Medal of Honor Recipients (A - L). United States of America. Disponível em: <http://www.army.mil/medalofhonor/citations25.html\#C >. Acesso em: 20 out. 2014.

CASTILHO, Alexandre Magno de. Almanach de Lembranças para 1852. Haward Colleg Library, 1906. Disponível em:

<https://books.google.com.br/books?id=TKIDAAAAYAAJ\&printsec=frontcover\&hl=ptBR\&source $=g b s \_g e \_s u m m a r y \_r \& c a d=0 \# v=$ onepage\&q\&f=false $>$. Acesso em: 20 out. 2014 .

CASTRO, José Luiz de. A organização da Igreja Católica na Capitania de Goiás (1726 - 1824). Goiânia: Editora da UCG, 2006.

CESARÉIA, Eusébio de. História Eclesiástica. Tradução de Monjas beneditinas do Mosteiro de Maria Mãe de Cristo. São Paulo: Paulus, 2000.

CORREIA, Aldenora Alves. Boa Vista do Padre João. Tocantinópolis: Edição da Autora, 1977.

COSTA, Thales Murilo Vaz. Opinião pública e linguagem política no A Matutina Meiapontense (1830-1834). 2013. Dissertação (Mestrado em História), Universidade Federal de Goiás, Goiânia.

ELIAS, Norbert. Os alemães: a luta pelo poder e a evolução do habitus nos séculos XIX e XX. Tradução de Álvaro Cabral. Rio de Janeiro: Zahar, 1997.

FITZ, Francisco Garcia. Edad Media: guerra e ideologia, justificaciones jurídicas y religiosas. Madrid: Sílex, 2003.

GIRALDIN, Odair. Catequese e civilização: os capuchinhos "entre" os "selvagens" do Araguaia e Tocantins. Bol. Mus. Para. Emílio Goeldi, sér. Ant. São Brás, Pará, v.18, n. 2, p.1-16, 2002. Disponível em:

<http://www.uft.edu.br/neai/file/odair_catequese_civilizacao.pdf >. Acesso em: 20 out. 2014 .

GROSSMAN, Dave. On Killing: The Psychological Cost of Learning to Kill in War and Society. New York: Back Bay Books, 1996.

LE GALL, Jean-Marie. A virilidade dos clérigos. In. CORBIN, Alain; COURTINE, JeanJacques; VIGARELLO, Georges. História da Virilidade. A invenção da virilidade da Antiguidade às Luzes. Petropólis, RJ: Editora Vozes, 2013. p 242-263 
MOREIRA, Igor Alves. Do bispo morto ao padre matador: Dom Expedito e o padre Hosana na construção da memória (1957/2004). 2008. Dissertação (Mestrado em História), Universidade Federal do Ceará, Fortaleza.

MOTA, Ireni Soares da; QUADROS, Eduardo Gusmão de. Deus, Pátria e Liberdade: um estudo sobre o Partido Católico em Goiás (1881-1909). Ciberteologia - Revista de Teologia \& Cultura - São Paulo, ano VII, n. 35. p. 33 - 44. Disponível em: $<$ http://ciberteologia.paulinas.org.br/ciberteologia/wpcontent/uploads/downloads/2011/o6/Artigo4.pdf>. Acesso em: 25 nov 2013.

NORONHA, João Antunes. Carta à Rainha D. Maria I. Vila Boa, 29 de junho de 1782. In: BERTRAN, Paulo (org.). Notícia Geral da Capitania de Goiás. v. 2. Goiânia: UCG, UFG; Brasília: Solo Editores, 1996. p. 64.

PAIVA, Marly. Padre durão de Pirenópolis agora usa tattoo e curte rock. 09 nov. 2007. Disponível em:

<http://www.filhosdapaixao.org.br/escritos/cartas/bispos/dom_manoel_pestana/dom_ manoel_18_anexo.htm.>. Acesso em: 21 out 2014.

PALACIN, Luís. O coronelismo no estremo norte de Goiás: o Padre João e as três revoluções de Boa Vista. Goiânia: UFG; São Paulo: Loyola, 1990.

RAMOS, Hugo de Carvalho. Tropas e Boiadas. Goiânia: Livraria e Editora Cultura Goiana, 1984.

SANTO AGOSTINHO. Confissões. Tradução de J. Oliveira Santos e A. Ambrósio de Pina. Coleção Os Pensadores. São Paulo: Editora Nova Cultural, 2000.

SGARIONI, Mariana. Padre bate em mulher em cerimônia de batizado. Folha online. São Paulo, 11 dez. 1997. Disponível em:

<http://www1.folha.uol.com.br/fsp/cotidian/ff111244.htm> Acesso em: 21 out. 2014.

SILVA E SOUZA, Luiz Antônio da. "Memória sobre o Descobrimento, Governo e População e Cousas mais Notáveis da Capitania de Goiás”. In: TELES, José Mendonça. (org.). Vida e obra de Silva e Souza. Goiânia: UFG, 1998. p. 71-139.

SILVA, Ademir Luiz. Da Grande Cruzada à Demanda do Graal - A História da Ordem dos Templários. Curitiba: Editora Prismas, 2014. (no prelo).

SILVA, Arlindo. O Brasil Condena as vítimas. Revista o Cruzeiro. Rio de Janeiro, 4 de junho de 1960. Disponível em:

<http://www.memoriaviva.com.br/ocruzeiro/o4061960/o4066o_3.htm>. Acesso em: 19 jan. 2015

SILVA, Cônego José Trindade da Fonseca e. Lugares e pessoas. Subsídios eclesiásticos para a história de Goiás. 2. ed. Goiânia: Editora da UCG, 2006. 
SILVA, Dom Eduardo Duarte. Passagens: autobiografia de Dom Eduardo Duarte Silva, Bispo de Goyaz. Goiânia: Editora da UCG, 2007.

VAINFAS, Ronaldo. Traição: um jesuíta a serviço do Brasil holandês processado pela Inquisição. São Paulo: Cia das Letras, 2008.

VATICANO, Rádio. Sacerdote ruandês condenado por genocídio. Cidade do Vaticano.14 dez 2006. Disponível em:

<http://pt.radiovaticana.va/storico/2006/12/15/sacerdote_ruand\%C3\%AAs_condenado _por_genoc\%C3\%ADdio/bra-108352>. Acesso em: 20 out 2014.

WEBER, Max. “Sociologia da Religião”. In: Economia e Sociedade. v. 1. Tradução de Regis Barbosa e Karen Elsabe Barbosa. Brasília: Editora da UnB, 1994. p. 279 - 418. 